\title{
LYON NATURAL RADIOCARBON MEASUREMENTS III
}

\author{
J. EVIN, G. MARIEN, and Ch. PACHIAUDI
}

I aboratoire de Radiocarbone du Département de Gćologie, Université de Iyon I, Institut de Physique nucléaire, 69 Villeurbanne, France

INTRODUCTION

The present list includes most of the samples measured since the establishment of the laboratory in 1965 and not yet published in the two previous dates lists.

Almost all the following samples were measured in the two proportional counters $(0.5$ effective volume filled with $3 \mathrm{~atm}$ CO. already described (R., 1969, v. 11, p. 112). The other measurements were made, using a liquid scintillation device, Model 3320 Tricarb. For routine counting the solution introduced in this detector is: 2 cc sample benzene, 13 cc inactive toluene, $0.4 \%$ PPO, $0.01 \%$ Dime POPOP. With this scintillator solution, background rate is about $10.1 \mathrm{cpm}$ and the modern standard about 21.3 cpm. For cach measurcment a quenching correction is made with a ratio of 2 counting channels. The maximum determinable age is equal to $30,000 \mathrm{yr}$.

Chemical treatments remain unchanged except for adoption of a purification procedure by adsorption on $\mathrm{Al}_{2} \mathrm{O}_{3}$. Benzene preparation is performed according to the method of Tamers (1965) i.e., Li., $\mathrm{C}_{2}$ formation at $625^{\circ} \mathrm{C}, \mathrm{C}_{6} \mathrm{H}_{6}$ production by trimerization of $\mathrm{C}_{3} \mathrm{H}_{2}$ on catalyst (K. C. Perl Catalysator neu, Kalic Chemic Cic). Preparation yields are $95 \%$ for $\mathrm{C}_{2} \mathrm{H}_{2}$ and $90 \%$ for $\mathrm{C}_{6} \mathrm{H}_{6}$. 'The detection yicld in the scintillator is ca. $65 \%$ and does not vary much with preparations.

The organic or carbonated samples are prepared in the classic way. For the bone samples we use the method of collagen extraction by solubilization in acid hot water. This method has been set up in the laboratory by R. Longin and summarized in (R., 1971, v. 19, p. 60-61) (see also Longin, 1971).

Ages are calculated using the half-life value 5570 with 1950 as reference year. The statistical errors, corresponding to one standard deviation, include the contribution of the contemporary standlard, background, and sample counting.

$\delta \mathrm{C}^{13}$ valucs of geologic and archateologic samples were measured with a mass spectrometer Model A.lE.I. MS 20 Isotopic, which ensures the routine $\mathrm{C}^{13}$ measurements since 1970 with a \pm 0.05 per mil precision. Age corrections have not been made on these results.

\section{ACKNOWLEDGMENTS}

We are grateful to J. Flandrin and P. Elouard, Department of Geology, for their continuous support, and to A. Sarazin, Dir. Nuclear Physic Institute, for his help and the technical assistance of his Institute. Also, we thank Y. Chiarlone for chemical preparations and most routine 
operations since Dec. 1970 , and we are indebted to the staff of the Institute, R. Viano and $C_{\text {. }}$ Devesa, for their technical help.

\section{SAMPLE DESCRIPTIONS}

I. GEOMOGIC SAMPIIS

Ly-280. Glacier du Chardon, Isère

$750 \pm 130$

A.D. 1200

Fragnent of tree trunk from marginal moraine, right bink of Glacier du Cihardon, near La Bérarde, Isère $\left(44^{\circ} 54^{\prime} \mathrm{N}\right.$ Iat, $6^{\circ} 18^{\prime} \mathrm{F}$ Long). Cioll. and subm. 1970 by R. Vivian, Inst. Géog. alpine, Grenoble. Comment (R.V.): presence of pine trunk, much higher than actual forest, marks warming phatse, preceding "little glacial-age" sensu stricto, a. 16th to 19th centuries. Optimal warming phase occurred in Middle ages, and date agrees well.

\section{Gorner Glacier series, Valais, Switzerland}

Picces of wood from alt. ca. $2000 \mathrm{~m}$ in marginal moraine, right bank of Corner Glacier, near Zermatt, Valais, Switzerland $\left(45^{\circ} 59^{\prime} \mathrm{N}\right.$ Lat, $7^{\circ}+14^{\prime}$ E Long). Coll. and subm, 1970 by R. Vivian.

\section{Ly-297. Gorner Glacier 1}

$7360 \pm 180$

Coll. at alt. of existing ice limit. 5410 ]B.C.

\section{Ly-298. Gorner Glacier 2}

$8160 \pm 220$ Coll. at alt $2050 \mathrm{~m}$.

6210 B.C.

Gencral Comment (R.V.): samples are oldest from moraines of alpine glaciers of Valais, at alt. where trecs no longer exist. Theses results and I.y-299 date ice retreat, higher than now, between 8000 and 5000 B.P. Dates may be compared to measurements from Mont-Blanc Massif (France-Italy) VRI-106: $5250 \pm 110$ and VRI-107: $6400 \pm 100$ (R., 1970, v. 12, p. 310 ).

\section{Ly-299. Glacier de Ferpècle, Valais, Switzerland}

$6950 \pm 150$

Tree trunk from alt. $1500 \mathrm{~m}$ in Les Haudières low valley, Val d'Herens, Valais $\left(46^{\circ} 5^{\prime} \mathrm{N}\right.$ Lat, $7^{\circ} 31^{\prime} \mathrm{E}$ Long) moved from alt. $1900 \mathrm{~m}$ by a debacle of Glacicr Ferpècle. Coll. and subm. 1970 by R. Vivian. Comment (R.V.): as Ly-297 and Ly-298, date warming phase which caused maximal retreat of alpine glaciers.

\section{Ly-490. Massif du Marsaou, Var}

Modern

$\delta C^{13}=-19.35 \%$

Bits of charcoal and woody fragments (Sphagnum plumosum and Polythium commune roots), included in red earth of rhyolite alteration from $\mathrm{N}$ side Massif du Marsaou, Esterel Massil, Var $\left(43^{\circ} 31^{\prime} \mathrm{N}\right.$ Lat, $6^{\circ}$ 55' E Long). Coll. and subm. 1971 by H. Triat, Lab. Bot. Hist. Palynol., Fac. Sci. Saint-Jćrôme, Marseille. Comment (H.T.): sample from $36 \mathrm{~cm}$ depth in pollen-analyzed soil. Analysis was made in order to follow 
forest evolution and to explain surprising presence of certain plant species at site. Result excludes hypothesis of ancient origin of Sphagnum.

Ly-363. Albigny, Rhône

A.D. 1490

$460 \pm 100$

Ox and ass bones from ditches of a castle at Albigny, Rhone $\left(45^{\circ}\right.$ $51^{\prime} \mathrm{N}$ Lat, $4^{\circ} 50^{\prime} \mathrm{E}$ Long). Coll. and subm. 1969 by C. Guérin, Dept. Sci. de la Terre, Univ. Lyon I. Comment (C.G.): bones come from either a geologic deposit in low terrace of Saône R., or, as suggested by this post-Gallo-Roman fauna, from an artificial earthwork. Date confirms later hypothesis.

\section{Ly-463. Costeplane, Alpes de Haute Provence}

$1980 \pm 130$

Charcoal from under landslide at Costeplane near Le Lauzet, Alpes de Haute Provence (44 $26^{\prime} \mathrm{N}$ Lat, $6^{\circ} 26^{\prime}$ E Long). Coll. and subm. 1970 by R. Chalavoux, Lyon. Comment (R.C.): age is maximum for landslide overlying charcoal whose age agrees with presence of indications of Roman occupation in region.

\section{Ly-426. Hière sur Amby, Isère}

$4630 \pm 140$

2680 B.C.

Fine charcoal debris included in calcareous tufa in Val d'Amby, near Hière sur Amby, Isère (45 $48^{\prime} \mathrm{N}$ Lat, $5^{\circ} 68^{\prime} \mathrm{E}$ Long). Coll. and subm by J. Flandrin, Dept. Sci. de la Terre, Univ. Lyon I. Comment (J.F.): proves calcareous tufa is ancient as expected from thickness of deposit, rather than modern.

\section{Ly-161. Laives, Saône et Loire}

$5380 \pm 180$

Wood from argillaceous sediment at Laives, Saône et Loire $\left(46^{\circ}\right.$ $10^{\prime} \mathrm{N}$ Lat, $4^{\circ} 49^{\prime}$ E Long). Coll. 1969 by P. Ciry and subm. by J. Combier, Dir. Antiquités préhistoriques, Ronanèche-Thorins, Saône et Loire. Comment (J.C.): wood was part of accumulation of big tree trunks in low terrace of R. Grosne valley. Deposit indicates large development of vegetation which, as expected, is postglacial and more precisely, of Atlantic Period. No pollen analysis was made.

\section{Ly-364. Le Pont des Clapets, Bouches du Rhône $\mathbf{3 6 5 0}$ в.C. \\ $5600 \pm 150$}

Peat at $4.10 \mathrm{~m}$ depth from boring in bog at Le Pont des Clapets,

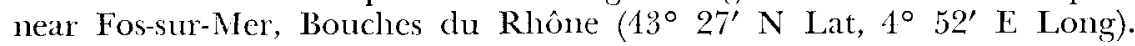
Coll. and subm. by H. Triat. Comment (H.T.): date supports pollen analysis in corresponding to Atlantic Period, with general forest expansion including species such as Quercus pubescus, Q. ilex, Pinus, Corylus, etc.

\section{Polliat series, Ain}

Wood from gravel pit excavated in Irance R. alluvia at Polliat, 
$\Lambda$ in $\left(46^{\circ} 14^{\prime} \mathrm{N}\right.$ Latt, $5^{\circ} 7^{\prime} \mathrm{E}$ l ong). Coll. and subm. 1967 by A. Billard, Centre de Recherches géog., Paris.

\section{Ly-240. Polliat 1}

From $1 \mathrm{~m}$ depth, base of silt layer.

\section{Ly-333. Polliat 2}

From same horizon at same depth as Ly-240.

\section{Ly-241. Polliat 3}

From center of trunk $1.7 \mathrm{~m}$ deep in coarse alluvia filling bottom of Irance $\mathbf{R}$. valley.

\section{Ly-334. Polliat 4}

$8490 \pm 180$

From another trunk in same level as Ly-241.

General Comment: Ly-241 and -334 date Boreal period, main filling of valley. Ly-240 and -333 prove upper silt layer of valley is recent.

\section{Ly-387. Meyzériat, Ain}

Modern

Wood from spoil created by dredging of Veyrle R. (same alluvial plain as Irance R.), near Meyzćriat, Ain ( $46^{\circ} 14^{\prime} \mathrm{N}$ Lat, $5^{\circ} 3^{\prime} \mathrm{E}$ Long). Coll. and sulom. 1967 by $A$. Billard. Comment: despite similarity to preceding samples, measurement proves, contrary to collector's supposition, sample does not come from dredged ancient alluvia.

\section{Ly-112. Enghien-les-Bains, Val d'Oise}

$11,240 \pm 330$

Peat included in argilaccocalcareous sand from $6 \mathrm{~m}$ depth at Enghien-les-Bains, Val d'Oise ( $48^{\circ} 56^{\prime} \mathrm{N}$ Lat, $2^{\circ} 15^{\prime} \mathrm{E}$ Long). Coll. 1967 by Solétanche Cie and subm. 1968 by A. Marcé, Bur. Recherches géol. et min., Orléans La Source. Comment (A.M.): sample from Quaternary formation just overlying Saint-Ouen Tertiary limestone. Age may correspond to Aller $\phi d$ interstade but no pollen analysis was made.

\section{Grotte Hué series, Alpes Maritimes}

Calcium carbonate from stalactite on roof of submarine grotto at -25 $\mathrm{m}$ depth. Grotte Huc, is offshore in Juan-les-Pins Gulf, Alpes Maritimes (433 $38^{\prime} \mathrm{N}$ Lat, $7^{\circ} 6^{\prime}$ E Long). Coll. 1970 by H. de Lumley, Fac. Sci. St. Charles, Marseille. Stalactite has 3 plain concentric growth rings.

\section{Ly-404. Grotte Hué, external part}

$10,500 \pm 150$

From external ring of stalactite.
8550 B.C.

$\delta C^{18}=-4.12 \%$ 


\section{Ly-403. Grotte Hué, median part}

From median ring of stalactite. No measurcment from central ring, which had central hole with traces of recrystallization.

General Comment: ages are calculated using $64.5 \%$ NBS standard as contemporary $\mathrm{C}^{14}$ value, according to $\mathrm{G}$. Delibrias measurements on stalactites from Aven of Orgnac, Ardèche (J. Iabeyric et al., 1967). Despite the fact that calculation is only approximate, dates agree with expected age of sea-level rise.

\section{Ly-360. Saint Maurice l'Exil, Isère}

$18,800 \pm 490$

Bones of mammal jaw from gravel pit near Saint-Maurice l'Exil, Isc̀re (45 23' N Lat, 4 $46^{\prime} \mathrm{E}$ Long). Coll. and subm. 1969 by C. Guérin. Pit is open in Rhône R. low terrace. Comment (C.G.): age, corresponding to end of Würm III, agrees with late Würm age for all low terraces of middle Valley of Rhône R. (David et al., 1972).

\section{Montrevel series, Ain}

Wood extracted by dredging from Reyssouze R. lowest alluvia near Montrevel Ain (46 $20^{\prime} \mathrm{N}$ Lat, $5^{\circ} 8^{\prime} \mathrm{E}$ Long). Coll. and subm. 1967 by A. Billard.

\section{Ly-246. Montrevel 5}

$21,100 \pm 500$

From ca. $8 \mathrm{~m}$ depth. Measurements made in normal conditions of $\mathrm{CO}_{2}$ pressure in a proportional counter.

\section{Ly-386. Montrevel 6}

From ca. $10 \mathrm{~m}$ depth, cat. $400 \mathrm{~m}$ downstream from Ly-246. Measurement made with scintillator detector used for preparing $\mathrm{C}_{6} \mathrm{H}_{6}$, the only quantity of $\mathrm{CO}_{2}$ normally used in a proportional counter. The experiment was made to compare statistical errors obtained.

General Comment: dates show decpest filling of this valley is much older than that of Irance R. (see Ly-241 and Ly-334, this list). It should correspond to cold phase in Würm III, considering Elephas primeginus and Rhinoceros ticorhinus found in same place at same depth.

\section{Ly-242. Les Pierrets-Viriat, Ain}

Fragments of big trec trunk coll. by boring between 9 and $14 \mathrm{~m}$ depth in Reyssouze R. lowest alluvia at Les Pierrets, near Viriat, Ain $\left(46^{\circ} 15^{\prime} \mathrm{N}\right.$ Lat, $5^{\circ} 11^{\prime} \mathrm{E}$ Long). Coll. and subm. 1967 by A. Billard. Site is $10 \mathrm{~km}$ downstream from Montrevel (Ly-246 and Ly-286, this list). Comment: expected age: same as Montrevel series, but appearance suggests it is redeposited Tertiary wood, such as already found on surface in Ain R. alluvia (see Iy-14, R., 1969, v. I1, p. 114). 


\section{Ly-437. Velars-Etrigny, Saône et Loire}

Mammal vertebrae from grotto at Velars. Coll. by "Les Blaireaux" Soc. and subm. by C. Gucrin. Comment (C.G.): fauna scems to be Würmian. Result eliminates attribution to Würm III or Würm IV.

\section{Ly-339. Fossil wood of Martigues, Bouches du Rhône $\geqslant \mathbf{3 5 , 0 0 0}$}

Fossil wood from $18 \mathrm{~m}$ depth in bedrock of ktang de Berre under Martigues Bridge, Bouches du Rhône (45 $24^{\prime} \mathrm{N}$ Latt, $5^{\circ} 3^{\prime}$ L Long). Coll. 1966 by P. Couprie and subm. by Y. Thommeret, Lab. Radiocarbone de Monaco. Comment: limit age agrces with the date MC-100: 35,000 \pm 4000 (R., 1969, v. 11, p. 119) from the same sample.

\section{Ly-166. Carotte T 3}

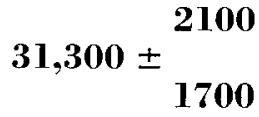

Calcareous-clayey marine mud from $1.85 \mathrm{~m}$ to $2.10 \mathrm{~m}$ below base of Mediterrancan Sea, near Mallorca I. Coll. 1963 and subm. 1968 by L. Leclaire, Lab. Gćol. du Mus., Paris. Measurement on total carbonate fraction; too little organic material to be extracted. Comment (I.I..): date a little older than expected, but part of carbonate fraction may be of terrigenous origin (Leclaire, 1972).

II. ARCHAEOLOGIC SAMPIES

\section{A. Historical and Bronze age periods}

\section{Ly-456. Sées, Orne}

Human bones found near Saint-Martin church at Sćes, Orne $\left(48^{\circ}\right.$ $36^{\prime} \mathrm{N}$ Lat, $0^{\circ} 10^{\prime} \mathrm{E}$ Long). Coll. and subm. 1970 by F. Evin, Sćes, Orne. Comment: expected age was Middle age due to importance of SaintMartin monastery during that period. Date proves maximal age is last century.

\section{Sévrier series, Haute Savoie}

Samples from coastal sta. submerged in Annecy Lake, near Sérricr, Haute Savoic ( $19^{\circ} 39^{\prime} \mathrm{N}$ Lat, $6^{\circ} 9^{\prime} \mathrm{E}$ Long). Coll. and subm. 1969 by R. Iaurent, Centre de recherches archćol. lacustres, Tréserves Savoie.

Ly-117. Sévrier, 267 A 2

$490 \pm 170$

\section{A.D. 1460}

Charcoal mixed with siliceous slag and iron oxide found with lacustrian chalk.

\section{Ly-273. Sévrier, 267 A 5}

$320 \pm 100$ sample.

Little woody twigs from lacustrian chalk layer near preceding

General Comment: Ly-273 dated to confirm Ly-117. Both dates confirm hypothesis that slag and iron oxides were contemporary with Bronze 
Final occupation of coastal sta. (Laurent, 1968). But presence of such material remains unexplained at this site.

\section{Ly-450. Le Plessis Grimoult, Calvados}

Charcoal from under a wall of medieval edifice at Le PlessisGrimoult, Calvados (48 $47^{\prime} \mathrm{N}$ Lat, $0^{\circ} 37^{\prime} \mathrm{W}$ Long). Coll. and subm. 1971 by M. de Boüard, Centre de recherches archéol. médiévales, Caen, Calvados. Comment (M. de B.): a little younger than expected, but, considering $200 \mathrm{yr}$ statistical range, a true age at start of 11 th century is quite consistent with other archaeol. data on site.

\section{Ly-68. Parc de la 'Tête d'Or, Lyon Rhône}

$1500 \pm 110$

Wood from a monoxyl barge found in 1862 in Rhône $R$. alluvia at Brénier-Cordon, Ain (Cordier, 1963), and now exhibited in town park La Tête d'Or, Lyon (45 $47^{\prime} \mathrm{N}$ Lat, 4 51' E Long). Coll. 1967 by J. Evin. Average of 2 measurements. Comment: barge expected to be from Bronze age, then date seems much too young, which may be due to an eventual impregnation of organic components made in order to preserve the timber. Date is possible; monoxyl barges remained in use until High Niddle age.

\section{Ly-455. Château de Saint-Germain $\quad 1160 \pm 150$ d'Ambérieu, Ain \\ A.D. 790}

Charred corn found over burial in Saint-Germain Castle, near Ambérieu en Bugey, Ain (45 $57^{\prime} \mathrm{N}$ Lat, $5^{\circ} 23^{\prime \prime} \mathrm{E}$ Long). Coll. and subm. 1971 by J. F. Reynaud, Centre de recherches médiévales, Univ. Lyon II. Comment: date agrees with expected age of burials, end of 7 th century.

\section{L'Hortus series, Hérault}

Charcoal from several levels of Palcochristian site in grotto of 1'Hortus, near Vallaunès, Hćrault ( $13^{\circ} 48^{\prime} \mathrm{N}$ Lat, $3^{\circ} 50^{\prime} \mathrm{E}$ Long). Coll. 1970 by G. Démians d'Archambault and subm. 1970 by H. de Lumley.

Ly-284. L'Hortus Zone 120, Level RC his

$1400 \pm 180$

Sample form Paleochristian offering-pit overlain by tumulus.

\section{Ly-283. L'Hortus Zone F8, Level B F}

$1610 \pm 190$

Sample from one of upper levels of large pit, E part of grotto, assoc. with Palcochristian material.

\section{Ly-282. L'Hortus Zone E7, Level F 4}

$$
1680 \pm 100
$$

Sample from one of lower levels of same pit as Ly-283, assoc. with older industry.

General Comment: comparison between Ly-284 and -282 scems to confirm that offering pits is younger than large pit. Both Ly-283 and -282 
are $100 \mathrm{yr}$ older than expected (5th and 4 th century) but remain in statistical range.

\section{Briord series, Ain}

Human bones from graves in several levels of Gallo-Roman cemetery at Les Plantis, near Briord, Ain (45 46 $\mathrm{N}$ Lat, 50 $27^{\prime} \mathrm{E}$ Long). Coll. and subm. 1967 by R. Perraud, La Mure-sur-Azergues, Rhône.

\section{Ly-454. Briord 284}

$1670 \pm 160$

Bones from grave $40 \mathrm{~cm}$ below actual soil. Comment: confirms late occupation of cemetery but older than expected age ( 7 th century) for that type of grave.

\section{Ly-61 bis. Briord 261 bis}

$1875 \pm 100$

Bones from same grave as Ly-61: $2060 \pm 200$ B.P. (R., 1969, v. 11, p. 114). Grave ca. $1.20 \mathrm{~m}$ below actual soil. Comment: new collagen preparation gives more precise date which better agrees with Emperor Tiberius' coins from another grave at same level.

\section{Ly-406. La Sartanette, Gard}

$2120 \pm 170$ 170 B.c.

Charred acorns from Iayer X, entrance of La Sartanette grotto, near Remoulins, Gard (43 $57^{\prime} \mathrm{N}$ Lat, $4^{\circ} 35^{\prime} \mathrm{E}$ I.ong). Coll. and subm. 1970 by A. Bonnet, Nimes. Comment (A.B.): assoc. with ceramic industries of "Ferric̀re" type but possibilities of mixing exist and are confirmed by date which agrees with Roman occupation of site, only $1 \mathrm{~km}$ from famous Pont du Gard bridge (Bonnet et al., 1971).

\section{Ly-500. L'Etoile d'Alaï, Lyon, Rhône}

$2370 \pm 160$

420 B.C.

Charcoal from Gallo-Roman settlement under modern building in Etoile d'Alä̈ urban quarter, Lyon, Rhône ( $45^{\circ} 45^{\prime} \mathrm{N}$ Lat, $4^{\circ} 47^{\prime} \mathrm{E}$ Long). Coll. and subm. 1969 by $\mathbf{L}$. Jeancolas, Tassin-la-demi-Lune, Rhone. Comment (J.L.): older than expected but with large statistical range; result can only mean that settlement was from lst Roman occupation in Lyon.

\section{Camp de Bierre series, Orne}

Charcoal from base of wall of promontory site Le Camp de Bierre, near Merri, Orne (48 $50^{\prime} \mathrm{N}$ Lat, $0^{\circ} 3^{\prime} \mathrm{W}$ Long). Coll. and subm. 1970 by G. Verron, Dir., antiquités préhistoriques, Caen, Calvados.

\section{Ly-464. Camp de Bierre 1}

From top of Layer IV from $110 \mathrm{~cm}$ to $120 \mathrm{~cm}$ depth. 


\section{Ly-465. Camp de Bierre 2}

From base of Layer IV from $120 \mathrm{~cm}$ to $130 \mathrm{~cm}$ depth.

\section{Ly-466. Camp de Bierre 3}

From Layer IV.

General Comment (G.V.): L.y-465 and -466 give Bronze Final age for building of promontory site. Ly-464, $400 \mathrm{yr}$ younger, indicates occupation of settlement continued till La Tène period (Vimont, 1884).

\section{Ly-95. Culoz Square II, Layer IV}

$3410 \pm 200$

Human bones from top Layer IV in $W$ part of Sous-Balme site at Culoz, $A$ in $\left(45^{\circ} 51^{\prime} \mathrm{N}\right.$ Lat, $5^{\circ} 47^{\prime} \mathrm{E}$ Long). Coll. 1961 and subm. 1966 by R. Vilain, Dépt. Géol., Univ. I yon I. Comment (R.V.): agrees with expected age but prescnce of Hallstatt and La Tène industries proves site was deeply excavated by recent tillage (Vilain, 1966).

\section{Ly-279. Shrew of Ashmin, Low Egypt}

$2400 \pm 140$

Mummified shrews (Crocidura sp., group dolichura) from an hypogeum at Ashmin, Low Egypt $\left(30^{\circ} 26^{\prime} \mathrm{N}\right.$ Lat, $30^{\circ} 58^{\prime} \mathrm{E}$ Long). Coll. 1900 by Lortet and Chantre and subm. 1969 by P. Mein, Dépt. Sci. de la Terre, Univ. Lyon I. Comment (P.M.): shrew species belongs to warm fauna of Guinean type, extinct in Egypt. Older date would suggest evolution of shrew species to extant species, but relatively recent value proves shrew subsisted a long time before becoming extinct (de Balzac and Mein, 1971).

\section{Ly-383. Nobles' Grave, Assouan, High Egypt \\ $4010 \pm 130$}

Wood from Nobles' Crave at hssoun, High Egypt (210 $\mathrm{I}^{\prime} \mathrm{N}$ Iat, $32^{\circ} 45^{\prime}$ E Long). Coll. by M. Baligan and subm. 1970 by R. Margrita, Centre d'études nucléaires de Grenoble, Isc̀re.

\section{B. Neolithic and Mesolithic periods}

\section{Ly-193. Le Rond du Lévrier, Haute Loire}

1860 B.C.

Burnt bones from rock shelter Le Rond du Lévrier, near Salette, Haute Loire ( $44^{\circ} 51^{\prime} \mathrm{N}$ Lat, $3^{\circ} 58^{\prime} \mathrm{E}$ Long). Coll. and subm. 1968 by A. Crémilleux, Le Monastier-sur-Gazeille, Haute Ioire. Comment (A.C.): same value as $\mathrm{Ly}-196: 4380 \pm 280$ (R., 1971, v. 13, p. 59) was expected. Younger date means either presence of Late Neolithic previously dated in another part of site: Ly-195: $3570 \pm 130$ (R. 1971, v. 13, p. 59), or mixing with bones coming from overlying levels. 


\section{Ly-385. Ilôt des Roseaux, Lac de Chalain, Jura}

$4640 \pm 140$

2690 B.C.

Wood from upper level, Level 0 of coastal sta. in Les Roseaux Islet, Chalain Lake near Doucier, Jura $\left(46^{\circ} 40^{\prime} \mathrm{N}\right.$ I at, $5^{\circ} 16^{\prime} \mathrm{E}$ Long). Coll. and subm. 1969 by P. Pétrequin, Dir. Antiquilés préhistoriques de Franche-Comtc, Besançon. Coastal sta. has several Late Neolithic levels (Levels 4 to 1 ) and base of Ievel 0 (Late Bronze) is last occupation of coastal sta. Comment (P.P.): instead of expected Late Bronze age date is Late Neolithic, indicating, after last occupation of coastal sta., lake croded its banks and deposited above Bronze level chatrcoal from underlying levels. Moreover, charcoal had floated aspect, and this type of apparent reversing of archaeologic layers is frequent in all coastal stas. dejendent on lake-level fluctuations.

\section{Ly-384. La Motte aux Magnins,} Lac de Clairvaux, Jura

$4640 \pm 270$ 2690 B.C.

Ciharcoal from Iate Neolithic hearth from upper part of $\mathrm{L}_{\text {a }}$ Motte aux Magnins coastal sta., Grand Lac, near Clairvaux, Jura $\left(46^{\circ} 34^{\prime} \mathrm{N}\right.$ Iat, $5^{\circ} 15^{\prime}$ E Long). Coll. and subm. 1969 by P. Pétrequin. Comment (P.P.): date scems a little too old for Iate Neolithic and fits with Middle Neolithic, but both civilizations might be partially contemporaneous in that country.

\section{Ly-335. Gondenans-lès-Montloy, Doul,}

$5490 \pm 140$

Charcoal from Level IX of Lat Tuileric oroto at Goudenans-lis Montly, Doubs $\left(47^{\circ} 26^{\prime} \mathrm{N}\right.$ Lat, $6^{\circ} 27^{\prime} \mathrm{E}$ Iong $)$. Coll. and subm. 1969 by P. Pétrequin. Comment (P.P.): level contains ceramic industry with stamped decomation, characteristic of "Rubané Récent Rösen" civilizattion. Same value as Gif-168: $5380 \pm 250$ (R., 1970, v. 12, p. 429) fiom I evel E. 6, Ia Bamne de Gonvillars, Jura, site which is in same region and has same industry (Pétrequin, 1970).

\section{La Hoguette series, Fontenay le Marmion, Calvados}

Charcoal and bones from Neolithic tumulus with a dry-stonc clolmen, at I a Hoguette, near Fontenay le Marmion, Calvados $49^{\circ} 6^{\prime}$ N Lat, 0 ${ }^{\circ}$ 29' W Long). (coll. 1966, 1968 and subm. 1967 and 1970 by R. Caillaud and E. I agnel, Caen, Calvados.

Ly-132. Tumulus de La Hoguette O/43

Charcoal from hearth overlying filling of Chamber $V$.

Ly.420. Tumulus de La Hoguette Ch VII Human bones from Chamber VII.

\section{Ly-421. Tumulus de La Hoguette Ch V}

Human bones from Chamber $V$.
$4580 \pm 150$

2630 в.c.

$5050 \pm 260$

3100 B.C.

$5160 \pm 190$

3210 B.C. 


\section{Ly-131. Tumulus de La Hoguette R/36}

Charcoal and hearth ash from Chamber VI.

General Comment (R.C. and E.L.): Ly-131, -420 , and -421 correspond to construction and utilization of tumulus and are in range of expected ages. Three values agree with date of charcoal from Chamber $V$ made by Gif-sur-Yvettc Radiocarbon lab.: $5000 \pm 130$ (R., 1972, v. 14, p. 280). Ly-131, however, is ca. 500 yr older than Ly-420, and Gif-1345. Difference can only be explained by statistical deviation. But Ly-132, 500 yr younger, corresponds to subsequent occupation of Chamber V (Caillaud and Lagnel, 1971).

\section{Ly-422. Bois Sacré, Gard}

$3890 \pm 140$

Charcoal from $30 \mathrm{~cm}$ to $80 \mathrm{~cm}$ depth in Bois-Sacré site, ncar Saint-

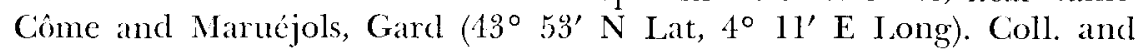
subm. 1969 by J. L. Roudil, Montpellier, Hérault. Assoc. with rich ccramic industry. Comment (J.L.R.): level is presumed contemporary of "Fontbouilsse" civilization and the date agrees well. Cif. date on Prével grotto at Montclus, Gard: Gif-191: $3880 \pm 180$ (R., 1966, v. 8, p. 84) (Roudil, 1969).

\section{Ly-462. Aven des Corneilles, Lozère}

$4630 \pm 110$

Charcoal from center of hearth assoc. with "Fontbouïsse" industry at l'Aven des Corneilles, near Prades, Loż̀re $\left(44^{\circ} 19^{\prime} \mathrm{N}\right.$ Lat, $3^{\circ} 27^{\prime} \mathrm{E}$ Long). Coll. and subm. 1970 by G. Fages, Sainte Enimie, Lozère. Comment (G.F.): hearth is between Middle Bronze burial level and Chalcolithic settlement. Expected date was similar to Ly-422: $3890 \pm 140$, this list, Bois sacré site. Other measurements on "Fontbouisse" civilization suggest Ly-162 is too old but rodent burrows might have carried charcoal in from underlying Chalcolithic horizon.

\section{Ly-458. Limonesque, Hérault}

$5510 \pm 200$

3560 B.C.

$\delta C^{1.3}=-20.49 \%$

Charcoal from La Baume II of Limonesque site, near Le Caylar, Hérault (44 $25^{\prime} \mathrm{N}$ Lat, $3{ }^{\circ} 3 \mathrm{I}^{\prime} \mathrm{E}$ Long). Coll. and subm. 1970 by G. B. Arnal, Montpellier, Hérault. Assoc. with Epicardial pottery industry, probably Atlantic period. Comment (G.B.A.): in expected range. Two other measurcments on same type of inclustry from Levels $2 \mathrm{~A}$ and $4 \mathrm{~A}$ of Saint-Pierre-de-la-Fage site, $11 \mathrm{~km}$ from Limonesque: Gif-2180: 5520 \pm 150 and Gil-1922: $6200 \pm 400$.

\section{Ly-491. Grotte du Maquis, Arlèche}

$5560 \pm 170$

3610 B.C.

$\delta C^{13}=-20.06 \%$

Charcoal from Ievel 4A, Grotte du Maquis, near Vallon Pont d'Arc, Ardeche (14. $23^{\prime} \mathrm{N}$ Lat, $4^{\circ} 24^{\prime} \mathrm{E}$ Long). Coll. and subm. 1970 by E. Tscherter, Roche de Nolière, Loire. Comment (E.T.): levels of 
grotto contain industries from Chassean until Protohistoric time, but sample is from level without characteristic industry. I evel 3 has 3 Chassean layers; date agrees with stratigraphic position of Level $4 \mathrm{~A}$ underlying I cevel 3.

\section{Ly-423. Grotte de Combe Ohscure}

$6400 \pm 160$

Charcoal from I evel 5, Giotto de Combe Ardiche $411^{\circ} 2 g^{\prime} \mathrm{Nat}, 1^{\circ}$, Gallèles, 8 E Long). Coll. 1969 by H. Saumade and subm. 1969 by J. I. Roudil. Assoc. with early Cardial industry. Comment (J.I..R.): Combe Obscure Grotto is most $\mathrm{N}$ settlement where Early Cardial industry has been found. Date conforms to expected result, and may be compared with I.y-303/304:6220 0100 (R., 1971, v. 13, p. 62): Iayer 1 Latte Cardial, Ia Baume de Montclus, Gard (Escalon de Fonton, $1970)$.

\section{Seuil des Chèvres series, Savoie}

Samples fiom several levels of Seuil des Chìves grotto, near Iat Ballue, Savoie ( $45^{\circ} 41^{\prime} \mathrm{N}$ Lat, $5{ }^{\circ} 21^{\prime} \mathbf{E}$ Long) (Vanbrugghe and Bill, 1968). Coll. and subm. 1969 by R. Vanbrugghe, Hellemes, Nord.

\section{$5300 \pm 180$}

Finc charcoal powcler from top of Layer IC. Comment $\mathbf{3 3 5 0}$ B.c. with Neolithic pottery with decomation comparable to Cardial or to Augy Sainte-Pollaye pottcry (Desbrosse, 1969). Same value as IJy-69: $52.10+100$ (R., 1969, v. 11, p. 116) from base of same layer. Both dates may be also compared with Neolithic Level E 6X at La Baume de Convillated, Doubs: Gil-468: $5980 \pm 250$ with similar assoc. pottery (R., 1970, v. 12, p. 129).

\section{Ly-389. Seuil des Chèvres E 7}

$6320 \pm 260$

Charcoal from hearth in Layer IV, assoc. with indeterminalsle pottery. Comment (R.V.): proves Iy-388 and Ly-389 hearths are not contemporary. Date secms too old for pottery in region but may be compared with Iayer G 10 XIb, La Baume de Gonvillard, Jura: Gif-469: $6250 \pm 300($ R., 1970 , v. 12, p. 429) end of Farly Neolithic.

\section{Ly-405. Seuil des Chèvres C 9}

$9700 \pm 150$

Bones from lower part of $I$ ayer $V$, assoc. with industry attributable to Epi-Paleolithic. Comment (R.V.): confirms previous less precise measurement from same level, Seuil des Cilìves E 6: Ly-70: $8980 \pm 400$ (R., 1969, v. 11. p. 116). Agrees well with assoc. fauna.

\section{Cours Moreau series, Macon, Saône et Loire}

Charcoal from digging $7 \mathrm{~m}$ deep under Cours Noreau, Sâne et Loire $\left(16^{\circ} 18^{\prime} \mathrm{N}\right.$ I at, $4^{\circ} 50^{\prime} \mathrm{E}$ I .ong). Coll. and subm. 1966 by S. Dacher, Channay-les-Macon, Saône et Ioire. 


\section{Ly-35. Cours Moreau, Level 1}

Ly-73. Cours Moreau, Level II

General Comment: both dates much older than expected, levels being attributed to "Roman" and "Celtic" ages.

\section{Laang Spean series, Cambodia}

Charcoal and bones from Laang-Spean grotto, Prov. Battambang,

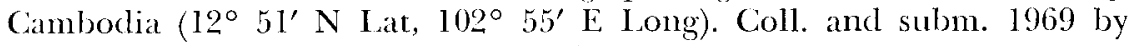
C. Mourer, Dept. Sci. de la Terre, Univ. Lyon I.

\section{Ly-265. Laang-Spean, Layer CRM}

$3380 \pm 150$

From 10 to $30 \mathrm{~cm}$ deptll.

\section{Ly-266. Laang-Spean, Layer CN} 1430 B.C.

From 30 to $50 \mathrm{~cm}$ depth.

\section{Ly-439. Laang-Spean, Layer CB}

$4740 \pm 100$ 2790 B.c.

From 50 to $70 \mathrm{~cm}$ depth.

General Comment: Iayers CRMI and CN contain Hoabinhian (Neolithic) industry with ceramics. Other charcoal from Layer CN was dated by Monaco Radiocarbon Iab.: MIC-273: $6270 \pm 70$. Layer CB contains earlier industry without ceramics which then appears between IIC-273 and Ly-439 (Nourer et al., 1970).

\section{Ly-408. Erg Admer, Sahara, Algeria}

$5420 \pm 130$

3470 B.c.

Burnt bovine bones found lying on sand dune in Tahor Passage in Lrg Admer, W Djanet, Algeria ( $24^{\circ} 29^{\prime} \mathrm{N}$ Lat, $9^{\circ} 10^{\prime} \mathrm{E}$ Long). Coll. and subm. 1970 by A. Bonnet, Nîmes. Assoc. with industries (ceramics, millstones, and flint) remained unaltered on sand dune. Comment (A.B.): date is minimum for dune formation. It is close to measurement of sample from 30 to $60 \mathrm{~cm}$ depth in Amekni site, Hoggar: Gif-461: 5500 \pm 250 (R., 1970, v. 12, p. 436) with assoc. Neolithic ceramic of Sudan tradition; it is also close to Meniet site: Gif: $5400 \pm 300$ and Jabbaren I: Gif: $5470 \pm 300$ (Camps et al., 1968).

\section{Ly-407. Erg Tichodaïne, Sahara, Algeria}

$$
\begin{gathered}
6870 \pm 150 \\
4920 \text { B.C. } \\
\delta C^{13}=-18.19 \%
\end{gathered}
$$

Humic black soil from Passage of Erg Tichodaine between Amguid and Fort-Gardet, Sahara, Algeria $\left(26^{\circ} 22^{\prime} \mathrm{N}\right.$ Lat, $6^{\circ} 50^{\prime} \mathrm{E}$ Long) Coll. and subm. 1970 by A. Bonnet. Comment (A.B.): agrees with expected age and with other dates of Sudan Ncolithic tradition (Camps et al., 1968). Sample assoc. with pottery was found on hillock isolated by deflation. Thus it is contemporary of oldest layer of Abouleg site, Hoggar: 
UW-89: $6860 \pm 100$, and of Deleba en Emedi site, Tchad: Gif-352: 6900 $\pm 300($ R., 1970, v. 12, p. 438).

\title{
C. Magdalenian period
}

\section{Ly-430. Grotte Colomb, Isère}

$8960 \pm 420$ 7010 B.C.

$8 C^{13}=-18.31 \%$

Marmot boncs from Grotte Colomb, near Mćaudre, Isc̀re $\left(45^{\circ} 9^{\prime}\right.$ N Lat, $5^{\circ} 33^{\prime}$ E Long). Coll. 1921 by H. Muller and subm. 1971 by $R$. Desbrosse, Blanzy, Saône et Loire. Comment (R.D.): assoc. industry was assumed Romanelian (Late Magdalenian and Azilian) (Bourdier and de Lumley, 1956) and contemporary of Dryas III period. Date does not fit with these assumptions but stratigraphy of digging is not well known and sampling remains questionable.

\section{Ly-451. Les Freydières, Drôme}

$$
11,380 \pm 180
$$

\section{0,430 в.C.}

$\delta C^{13}=-14.47 \%$

Bones from only layer of Les Freydières grotto site, near SaintAgnan en Vercors, Drôme (44 $58^{\prime} \mathrm{N}$ Lat, 5 26 $6^{\prime} \mathrm{E}$ Long). Coll. 1965 and subm. 1971 by A. Bocquet, Inst. Dolomieu, Grenoble, and R. Desbrosse. Comment (A.B., R.I.): layer is attributed to Magdalenian VI. Date is younger than I y-136: $12,800 \pm 300$, this list, from Campalou, site of same region. Difference may be due to more isolated geographic position and to alt. of Les Freydic̀res site (Bocquet, 1969).

\section{Ly-452. La Baume Loire II, Haute Loire}

\author{
$3950 \pm 120$ \\ 2000 B.C. \\ $\delta C^{13}=-1 . .38 \%$
}

Black earth from Rock Shelter II at La Baume Loire, near Solignac, Haule Loire $\left(44^{\circ} 56^{\prime} \mathrm{N}\right.$ Lat, $3^{\circ} 54^{\prime} \mathrm{E}$ Long). Coll. and subm. 1970 by A. Crómilleux, Le Monastier sur Gazeille, Haute Loire. Comment (A.C.): this black eanth contains Late Paleolithic industry but archaeologic level is composed of rubble stones between which elements of overlying levels might be descended.

\section{Ly-356. Grotte des Romains Niveau III, Ain}

$12,980 \pm 240$

11,030 в.c.

Bones from Level III at Grotte des Romains Near Virignien, Ain (45 $41^{\prime} \mathrm{N}$ Lat, $5^{\circ}$ 2 $\mathrm{l}^{\prime} \mathrm{E}$ Long). Coll. and subm. 1969 by R. Desbrosse. Comment (R.D.): date agrees better with expected age than previous measurement, L.y-16: 14,380 \pm 380 (R., 1969, v. 11, p. 116) of charcoal from same level (Evin and Desbrosse, 1971).

\section{Pont des Douattes series, Haute Savoie}

Bones from Late Magdalenian level at Le Pont des Douattes rock shelter, near Mlussiège, Haute-Sivoic $\left(46^{\circ} 0^{\prime} \mathrm{N}\right.$ Lat, $5^{\circ} 58^{\prime} \mathrm{E}$ Long). 


\section{Ly-435. Les Douattes, Level 7}

$12,480 \pm 260$

10,530 B.C.

$\delta C^{12}=-15.04 \%$

Coll. 1931 and subm. 1971 by A. Jayet, Geneva (Jayet, 1932).

\section{Ly-453. Les Douattes, Level b}

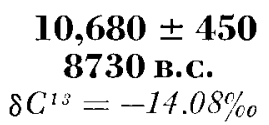

Coll. 1959 by I. Pradel and subm. 1971 by R. Desbrosse (Pradel and Pradel, 1960).

General Comment (R.D.): both Levels 7 and b correspond to same Late Magdalenian horizon. 'Then Ly-4.53 is probably contaminated and Ly-435 agrees well with industry and may be compared with Ly-356: 12,980 \pm 240, this list, from Level III Les Romains grotto.

\section{Ly-440. Blois-sur-Seille, Jura}

$12,040 \pm 270$

Bones from only level of Le Chamois Boivin grotto, near Blois-surSeille, Jura $\left(46^{\circ} 45^{\prime} \mathrm{N}\right.$ Lat, $5^{\circ} 40^{\prime} \mathrm{E}$ Long). Coll. 1953 by N. Vuillemey and subm. 1971 by R. Desbrosse. Comment (R.D.): agrees with expected Magdalenian VI age and with fauna which indicates a dry and cold climate, end of Wurm IV (Gauthier, 1955).

\section{Ly-436. Campalou, Drôme}

$12,800 \pm 300$

10,850 B.C.

$\delta C^{13}=-16.17 \%$

Bones from Campalou rock shelter near Saint-Nazaire-en-Royan, Drôme (45 $15^{\prime} \mathrm{N}$ Lat, 5 $5^{\circ}$ 12' E Long). Coll. and subm. 1970 by J. and J. Brochier, Romans, Drôme. Assoc. with Late Magdalenian industry with Azilian characters. Comment (J. and J.B.): date proves, despite Azilian character, this Magdalenian is rather old. Cf. Les Deux-Avens grotto: Ly-321/322: 12,340 \pm 200 (R., 1971, v. 13, p. 63).

\section{Solutré series, Saône et Loire}

Bones from Level P. 16, Sq. 88-89, Solutré site, Saône et Loire $\left(46^{\circ}\right.$ 18' N Lat, 4० 43' E I.ong). Coll. and subm. 1969 by J. Combier, Dir. régionale Antiquités prélistoriques, Romanèche-Thorins, Saône et Loire. Site is mainly composed of thick mass of horse bones in large rock rubble at foot of limestone cliff.

\section{Ly-392. Solutré 15}

$3350 \pm 350$

Burned bones treated as unburned bones, i.e., by collagen extraction. Comment (J.C.): unexplained high pollution.

$12,580 \pm 250$

Ly-393. Solutré 16

10,600 B.C.

Unburned bones. Comment (J.C.): perfect agreement with assoc. 
Late Magdalenian industry. Date marks last occupation of site and encl of formation large rock rubble with horse bones whose same levels were previously dated: see Ly-313/315/316 and Ly-317 (R., 1971, v. 13, p. 63-61).

\section{Ly-425. Enval Layer XII, Puy de Dôme}

$$
13,000 \pm 300
$$

\section{1,050 B.C.}

$$
\delta C^{1 .}=-22.73 \%
$$

Earth with fine charcoal fragments from Latyer XII in Enval site. near Vic-le-Comte, Puy-de-Iôme $\left(45^{\circ} 29^{\prime} \mathrm{N}\right.$ Lat, $3^{\circ} 1^{\prime} \mathrm{E}$ Long). Coll. and subm. 1970 by Y. Bourdelle, Clermont-Ferrand, Puy-de-Dôme. Comment (Y.B.): layer corresponds to beginning of Late Magdalenian. It is in rock rubble which might be contemporary with volcanic explosion phase dated ca. 12,800 B.P. Date is maximum for statuette "Venus of Enval" $5 \mathrm{~cm}$ above hearth dated here (Bourdelle $e t$ al., 1971).

\section{Saint-Roman series, Isère}

Bones from 2 levels in Le Calvaire rock shelter, near Saint-Roman, Isc̀re (45 $7^{\prime} \mathrm{N}$ Lat, $5^{\circ} 20^{\prime} \mathrm{E}$ Long). Coll. 1921 by $\mathrm{H}$. Muller and by $\mathrm{F}$. Bourdier 1938, and subm. by R. Desbrosse and A. Bocquet (Bourdier and de Lumley, 1956).

\section{Ly-431. Saint-Roman Series III}

$$
\begin{gathered}
\mathbf{1 2 , 9 7 0} \pm \mathbf{3 0 0} \\
\mathbf{1 1 , 0 2 0} \text { в.c. } \\
\delta C^{1.3}=-17.21 \%
\end{gathered}
$$

\section{Ly-432. Saint-Roman Series IV}

General Comment (R.D.): both dates agree with stratigraphy and with Late Magdalcnian industry. As expected, Series III (Ly-431) may be contemporary with Level III of La Grotte des Romains site. But expected age of Series IV (L.y-432) was a little younger.

\section{Ly-433. La Colombière, Ain}

$13,390 \pm 300$

11,440 B.c.

$\delta C^{13}=-17.44^{\%} \%$

Fragment of mammoth bone from Level $\mathrm{D}$ in La Colombière rock shelter, near Neuville-sur-Ain, Ain ( $46^{\circ} 5^{\prime} \mathrm{N}$ Lat, $5^{\circ} 22^{\prime} \mathrm{E}$ Long). Coll. 1913 by L. Nayet and J. Pissot (Mayct et Pissot, 1915) and subm. 1971 by R. Desbrosse. Assoc. with art work (specially engraved pebbles). Comment (R.D.): 4 other $\mathrm{C}^{14}$ measurements exist from site. The nearest result is: $L-177: 14,150+400$ (Science, v. 126, p. 1329); other results are W-150: $11,750 \pm 600$ (Science, v. 121, p. 187); L: $15,500 \pm 700$ and $\mathrm{L}$ : $14,700 \pm 300$ (Novius and Judlson, 1956). I.y-433 seems a little too young to archaeologists who attribute industry of site to Leroi-Gourhan's Style IV Magdalenian. 


\section{La Croze-sur-Suran series, Ain}

Mammoth bone from only level, attributed to Magdalenian III of La Croze-sur-Suran site, near Saint-Martin-du-Mont, Ain $\left(46^{\circ} 5^{\prime} \mathrm{N}\right.$ Lat, $5^{\circ} 21^{\prime}$ E Long). Coll. 1913 by J. Tournier and T. Costa de Beauregard (Tournier et Costa de Beauregard, 1922) and subm. 1971 by $R$. Desbrosse.

\section{Ly-357. La Croze-sur-Suran 1}

\section{Ly-434. La Croze-sur-Suran 2}

$14,330 \pm 260$ 12,380 в.с.

$14,850 \pm 350$ 12,900 B.C.

$\delta C^{13}=-15.15 \%$

General Comment (R.D.): both dates correspond to each other. The difference of 1000 to $1500 \mathrm{yr}$ between these 2 Magdalenian III dates and those of preceding Late Magdalenian sites is quite possible. But connections between La Croze-sur-Suran and neighboring site, La Colombière, remain indeterminate.

\section{Ly-361. Esclauzure, Corrèze}

$14,540 \pm 300$

Mammal bones from filling of grotto at Esclauzure, near Lissac, Corrèze (45. $18^{\prime} \mathrm{N}$ Lat, $1^{\circ} 28^{\prime} \mathrm{E}$ Long). Coll. 1970 by P. Andricu and subm. 1970 by C. Guérin. Comment (C.G.): estimated age was Early Magdalenian or Solutrean considering similarity of lithic industry of site with that of neighboring grotto Badegoulc. Date rather suggests a Magdalenian age (Andrieu, 1971).

\section{HYDROGEOI.OGIC SAMPLES}

The following samples come from several aquifers of France or Africa, coll. 1967-70 by Bur. Recherches Géol. et Min. Selection of sampling points, supervision of chemical preparations on ground, and analysis of results were made by Y. Vuillaume, Dept. Géol. Aménagement, Bur. Recherches Géol. et Min. Orléans La Source, Loiret. Carbonate species were extracted at simpling sites by $\mathrm{BaCO}_{3}$ precipitated, adding $\mathrm{NaOH}$ and $\mathrm{BaCl}_{2}$ in a $100 \mathrm{~L}$. metal tank, then sent to the radiocarbon lab. either as a dry $\mathrm{BaCO}_{3}$ precipitate, or a $2 \mathrm{~L}$ flask filled with $\mathrm{BaCO}_{3}$ unseparated from NaOH solution. Radiocarbon content is reported as $\%$ of modern without correction from $\delta \mathrm{C}^{13}$ measured by $\mathrm{R}$. Letolle, Lab. Gćol. Dynamique, Univ. Paris VI.

\section{Rhône delta series, France}

Ground water samples in Rhône R. alluvia in its delta, near Fossur-Mer, Bouches du Rhône. Dated 1969 to cletermine extent of a "saltintrusion" in alluvia bordering Gulf of Fos, W Mediterranean Sea. 


\begin{tabular}{|c|c|c|c|c|c|c|}
\hline & Simples & N Latt & E Long & $\begin{array}{c}\text { Ions CI- } \\
\text { Ppm }\end{array}$ & $\begin{array}{l}\delta C^{13} \\
\pm 0.15\end{array}$ & $\begin{array}{l}\mathrm{Ci}^{14 \%} \\
\text { modern }\end{array}$ \\
\hline Ly-182. & $\begin{array}{l}\text { I a Fromatgere Well X } \\
\text { 2. Fresli lree ground } \\
\text { water }\end{array}$ & $\left(43^{\circ} 28^{\prime}\right.$ & $\left.4^{05} 3^{\prime}\right)$ & 32 & $-10.55 \%$ & $81.2 \% \pm 1.4$ \\
\hline Ly-200. & $\begin{array}{l}\text { Ices Clapets Well X Ibis. } \\
\text { Fresh water underlying } \\
\text { salt confuned ground } \\
\text { water }\end{array}$ & $\left(133^{\circ} 27^{\prime}\right.$ & $\left.1^{\circ}, 52^{\prime}\right)$ & 106 & $-14.09 \%$ & $79.1 \%+0.9$ \\
\hline Ly-199. & $\begin{array}{l}\text { Ratlincric de fos Well } \\
\mathrm{X} 3 . \text { Brackish confined } \\
\text { ground water }\end{array}$ & $\left(43^{\circ} 26^{\prime}\right.$ & $4^{\circ} 5\left(\mathrm{j}^{\prime}\right)$ & 6780 & $-17.61 \%$ & $74.3 \% \pm 1.9$ \\
\hline L.y-198. & $\begin{array}{l}\text { Salin de Caban Well X } \\
6 . \text { Salt confined ground } \\
\text { water }\end{array}$ & $\left(43^{\circ} 29\right)^{\prime}$ & $\left.4^{\circ} 43^{\prime}\right)$ & 20,200 & $-5.38 \%$ & $45.8 \% \pm 1.7$ \\
\hline
\end{tabular}

Gomeral Comment (Y.V.): (1-t contents inclicate that apparent age of water increases with ion $\mathrm{Cl}-$ content. Water from $\mathrm{X} 6$ well (Ly-198) secms taipped since some miliemia likely since aquifer was formed.

\section{Ground water of Calcaire Carbonifère of Bassin du Nord series, France and Belgium}

The following samples, subm. 1969-70 come from ground water in calcareous aquifer, ca. $100 \mathrm{~m}$ deep, I.ille region, Nord. Coll. April, 1969 during a gencral study of ground water to determine its supply and renewal conclitions.

Some (14 measurements of boring-cutting from the aquifer were also made to determine an eventual exchange between water and calcareous matrix of aquiler.

\begin{tabular}{|c|c|c|c|c|}
\hline & Ground water samples & N Lat E Long & $\begin{aligned} & \delta \mathrm{C}^{13} \\
\pm & 0.15\end{aligned}$ & $\begin{array}{l}\mathrm{C}^{14 \%} \% \\
\text { modern }\end{array}$ \\
\hline I $>y-25 \%$ & Antoine $: 693$, Belgium & $\left(50^{\circ} 34^{\prime} \quad 3027^{\prime}\right)$ & $-18.57 \%$ & $65.5 \% \pm 1.0$ \\
\hline I. y-2.58. & Saint-1 ćger 362 , Belgium & $\left(50^{\circ} 42^{\prime} \quad 3^{\circ} 18^{\prime}\right)$ & - & $41.1 \% \pm 0.8$ \\
\hline Ly-251. & Annapes Sen 351, France & $\left(50^{\circ} 38^{\prime} \quad 3^{\circ} 9^{\prime}\right)$ & $-11.74 \%$ & $41.40 \pm 0.8$ \\
\hline Ly-252. & $\begin{array}{l}\text { Roubaix A. Motte } 353 \text {, } \\
\text { Fuance }\end{array}$ & $\left(50^{\circ} 12^{\prime} \quad 3^{\circ} 10^{\prime}\right)$ & $-10.36 \%$ & $32.9 \%=0.7$ \\
\hline L. $y-253$ & $\begin{array}{l}\text { Lille Grande Brasseric } 354 \text {, } \\
\text { France }\end{array}$ & $\left(50^{\circ} 38^{\circ} 33^{\circ}\right)$ & $-2.48 \%$ & $21.9 \% \pm 0.9$ \\
\hline $1, y-257$ & Mouscron 361 , Belgium & $\left(50^{\circ} 45^{\prime} \quad 3^{\circ} 12^{\prime}\right)$ & $-11.62 \%$ & $15.6 \% \pm 0.6$ \\
\hline I $y-250$ & Mouscron 360, Belgium & $\left(50^{\circ} 45^{\prime} \quad 3^{\circ} 12^{\prime}\right)$ & $-10.48 \%$ & $12.6 \% \pm 0.6$ \\
\hline $1.25-25$. & $\begin{array}{l}\text { Frelingheim Gillet Thaon } \\
358 \text {, France }\end{array}$ & $\left(50^{\circ} 43^{\prime} \quad 2^{\circ} .56^{\prime}\right)$ & $+0.25 \%$ & $12.6 \% \pm 2.3$ \\
\hline Ly-268. & Commines 357, France & $\left(50^{\circ} 16^{\prime} \quad 3^{\circ} 0^{\prime}\right)$ & $-3.77 \%$ & $<1.6 \%$ \\
\hline Ly-254. & Halluin Cratry 356, France & $\left(50^{\circ} 17^{\prime} \quad 3^{\circ} 0^{\prime}\right)$ & $-2.48 \%$ & $<1.9 \%$ \\
\hline
\end{tabular}




\begin{tabular}{|c|c|c|c|c|c|}
\hline & Cutting samples & $\mathrm{N}$ Lat & E Long & $\begin{array}{c}\delta \mathrm{C}^{13} \\
\pm 0.15\end{array}$ & $\begin{array}{l}\mathrm{C}^{110 \%} \\
\text { modern }\end{array}$ \\
\hline I. $y-291$. & $\begin{array}{l}\text { Lille Grande Brasserie, } \\
-54 \mathrm{~m} 364 \text {, France }\end{array}$ & $\left(50^{\circ} 98^{\prime}\right.$ & $\left.3^{\circ} 2^{\prime}\right)$ & - & $<1.9 \%$ \\
\hline L.y-292. & $\begin{array}{l}\text { Lille Grande Brasserie, } \\
-80 \mathrm{~m} 365 \text {, France }\end{array}$ & $\left(50^{\circ} 38^{\prime}\right.$ & $\left.3^{\circ} 2^{\prime}\right)$ & $-5.35 \%$ & $<1.6 \%$ \\
\hline Ly-293. & 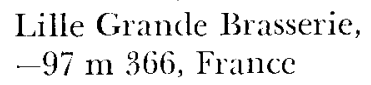 & $\left(50^{\circ} 38^{\prime}\right.$ & $\left.3^{\circ} 2^{\prime}\right)$ & $+4.37 \%$ & $<1.7 \%$ \\
\hline Ly-294. & $\begin{array}{l}\text { Wambrechies Dièves, } \\
-91 \mathrm{~m} 368 \text {, France }\end{array}$ & $\left(50^{\circ} 11^{\prime}\right.$ & $\left.3^{\circ} 3^{\prime}\right)$ & $+1.82 \%$ & $<1.9 \%$ \\
\hline L. $y-295$. & $\begin{array}{l}\text { Wambrechies Calcaire } \\
-125 \mathrm{~m} 369 \text {, France }\end{array}$ & $\left(50^{\circ}+11^{\prime}\right.$ & $\left.3^{\circ} 3^{\prime}\right)$ & $+1.52 \% 0$ & $<2.1 \%$ \\
\hline
\end{tabular}

General Comment (Y.V.): a dissolution of carbonates, confirmed by $\delta \mathrm{C}^{13}$ values, entails very old apparent ages. Radioactivity decreases toward $W$ part of basin in opposite direction of supply zone, localized toward E. Null values of cutting samples indicate that any exchange of detectable amounts of $\mathrm{C}^{1.4}$ active carbonate occurred in the aquifer between rocks and water.

\section{Ground water of the Craie of Bassin du Nord series, France}

Samples subm. 1969, 1970, from ground water in a chalky aquifer. Coll. April, 1969 during a general study of ground water to determine its supply and renewal conditions. This ground water is above Calcaire Carbonifère ground water. Its depth increases from $E$ to $W$ parts of basin where it becomes confined.

\begin{tabular}{|c|c|c|c|c|}
\hline & Water samples & N Lat L Long & $\begin{array}{c}\delta C^{i 3} \\
\pm 0.15\end{array}$ & $\begin{array}{l}\mathrm{C}^{140 \%} \\
\text { modern }\end{array}$ \\
\hline L.y-262. & $\begin{array}{l}\text { Lille Grande Brasserie } \\
355\end{array}$ & $\left(50^{\circ} 38^{\prime} 3^{\circ} 2^{\prime}\right)$ & 一 & $79.0 \% \pm 1.0$ \\
\hline I.y-261. & Annapes Sen 352 & $\left(50^{\circ} 98^{\prime} \quad 3^{\circ} 9^{\prime}\right)$ & - & $56.1 \% \pm 0.9$ \\
\hline Ly-263. & $\begin{array}{l}\text { Frelingheim La } \\
\text { Houlette } 359\end{array}$ & $\left(50^{\circ} 43^{\prime} \quad 2^{\circ} 56^{\prime}\right)$ & $-12.98 \%$ & $20.5 \% \pm 0.9$ \\
\hline Ly-260. & $\begin{array}{l}\text { Wambrechies Distilleric } \\
350\end{array}$ & $\left(50^{\circ} 41^{\prime} \quad 3^{\circ} 3^{\prime}\right)$ & $-0.78 \%$ & $<2.0 \%$ \\
\hline
\end{tabular}

General Comment (Y.V.): in its free part, ground water is normally supplied by rain water. $\mathrm{C}^{14}$ contents indicate that in confined part, the supply of ground water is slow. As in Calcaire Carbonifère ground water, radioactivity decreases to $W$ part of aquifer.

\section{Ground water of the Albian of Sahara series}

Samples subm. in 1968 and 1969 from ground water in sands of $\mathrm{N}$ Sahara Albian. Study was to determine supply conditions of aquifer. 


\begin{tabular}{|c|c|c|c|c|}
\hline Water samples & N Lat & E Long & $\begin{array}{c}\delta \mathrm{C}^{13} \\
\pm 0.15\end{array}$ & $\begin{array}{l}\mathrm{C}^{14 \%} \% \\
\text { modern }\end{array}$ \\
\hline Ly-153. Laghouat II 276 & $\left(33^{\circ} 46^{\prime}\right.$ & $\left.2^{\circ} 53^{\prime}\right)$ & $-11.50 \%$ & $108.6 \% \pm$ \\
\hline Ly- 77. Laghouat I 275 & $\left(33^{\circ} 46^{\prime}\right.$ & $\left.2^{\circ} 53^{\prime}\right)$ & $-7.76 \%$ & $58.5 \% \pm 1.2$ \\
\hline Ly-158. Ouargla littante 311 & $\left(32^{\circ} 0^{\prime}\right.$ & $\left.5^{\circ} 18^{\prime}\right)$ & - & $18.6 \% \pm 1.1$ \\
\hline Ly-159. Tougourt Ain Thaleb 312 & $\left(33^{\circ} 5^{\prime}\right.$ & $\left.6^{\circ} 6^{\prime}\right)$ & 一 & $18.4 \% \pm 1.5$ \\
\hline Ly- 75. Bou Azoua 279 & $\left(33^{\circ} 46^{\prime}\right.$ & $\left.7^{\circ} 28^{\prime}\right)$ & $\rightarrow$ & $17.0 \% \pm 0.8$ \\
\hline Ly-155. Tougourt Sidi Mandi 295 & $\left(33^{\circ} 5^{\prime}\right.$ & $\left.6^{\circ} 6^{\prime}\right)$ & $-11.60 \%$ & $13.3 \% \pm 1.3$ \\
\hline Ly- 76. Zellana II 280 & $\left(32^{\circ} 24^{\prime}\right.$ & $\left.4^{\circ} 12^{\prime}\right)$ & $-7.61 \%$ & $11.2 \% \pm 0.7$ \\
\hline Ly-154. Berriane II 278 & $\left(32^{\circ} 50^{\prime}\right.$ & $\left.3^{\circ} 47^{\prime}\right)$ & $-5.70 \%$ & $10.5 \% \pm 1.4$ \\
\hline Ly-156. Tougourt Ranou 301 & $\left(33^{\circ} 5^{\prime}\right.$ & $\left.6^{\circ} 6^{\prime}\right)$ & $-3.70 \%$ & $10.7 \% \pm 1.2$ \\
\hline Ly-157. Ouargla II 294 & $\left(32^{\circ}\right)^{\prime}$ & $\left.5^{\circ} 18^{\prime}\right)$ & - & $10.1 \% \pm 0.7$ \\
\hline
\end{tabular}

General Comment (Y.V.): values indicate gradient of apparent ages from $N$ part of aquifer (waters the youngest) to SE part (water the oldest).

\section{Several aquifers in Tchad series}

Samples subm. 1967, 1968 by Bur. Recherches Gćol. et Min. FortLamy, Ichad, and coll. by J. I. Schneider of the Bureau.

\begin{tabular}{|c|c|c|c|c|c|}
\hline & Water samples & N Lat & E Long & $\begin{aligned} & \delta \mathrm{C}^{13} \\
\pm & 0.20\end{aligned}$ & $\begin{array}{l}\mathrm{C}^{140 \%} \\
\text { modern }\end{array}$ \\
\hline Ly- 53. & $\begin{array}{l}\text { Koro-Toro } 248 \\
\text { Free ground water in } \\
\text { Pliocenc }\end{array}$ & $\left(18^{\circ} 30^{\prime}\right.$ & $\left.16^{\circ} 5^{\prime}\right)$ & ca. $-7.50 \%$ & $81.1 \% \pm 1.5$ \\
\hline Ly- 52. & $\begin{array}{l}\text { Abou-Garga } 204-247 \\
\text { Confined ground water in } \\
\text { Pliocene }\end{array}$ & $\left(16^{\circ} 25^{\prime}\right.$ & $\left.11^{\circ} 50^{\prime}\right)$ & $-5.27 \%$ & $64.2 \% \pm 1.0$ \\
\hline Ly- 54. & $\begin{array}{l}\text { If éna R } 2203-237 \\
\text { Confined ground water in } \\
\text { Continental }\end{array}$ & $\left(18^{\circ} 45^{\prime}\right.$ & $\left.13^{\circ} 30^{\prime}\right)$ & ca. $-7.50 \%$ & $64.6 \% \pm 1.2$ \\
\hline$L y-160$. & $\begin{array}{l}\text { Largeau } 261-265 \\
\text { Artesian ground water in } \\
\text { Primary }\end{array}$ & $\left(19^{\circ} 5^{\prime}\right.$ & $\left.17^{\circ} 55^{\prime}\right)$ & 一 & $37.5 \% \pm 0.9$ \\
\hline $\mathrm{I} y-65$. & $\begin{array}{l}\text { Bokoyo } 211 \\
\text { Deep confined ground water } \\
\text { in Pliocene }\end{array}$ & $\left(15^{\circ} 40^{\prime}\right.$ & $\left.12^{\circ} 0^{\prime}\right)$ & - & $5.5 \% \pm 0.5$ \\
\hline Ly- 51. & $\begin{array}{l}\text { Abou-Baran } 244 \\
\text { Deep confined ground water } \\
\text { in Pliocene }\end{array}$ & $\left(15^{\circ} 50^{\prime}\right.$ & $\left.12^{\circ} 10^{\prime}\right)$ & ca. $-7.50 \%$ & $4.2 \% \pm 0.6$ \\
\hline
\end{tabular}

Gencral Comment (Y.V.): measurements performed on several aquifers to determine approx. recharge date. No general conclusion can be drawn, without more results. 


\section{Ly-232. Zouerat, Mauritania}

$46.6 \pm 0.9 \%$ modern

$\delta C^{1 *}=-10.63 \pm 0.20 \%$

Water sample from ferruginous quartzite of Zouerat, Mauritanic. Sample coll. to study water supply of iron mines. Comment (Y.V.): this only result suggests water is renewed slowly which is propitious element for mining.

\section{REILRINCI:S}

Andricu, P., 1971, La Grotue d'Esclauzure près de Isissac, Corrèc; étude palćontologique par C. Guérin: Mélange Vazcille; F. Ogier Imp. I ulle.

de Balzac, H. and Mein, P., 1971, Les musaraignes momifices des loypogées de 'Ihèbes: Mamalia, v. 35, p. $220-21$.

Bocquet, A., 1969, L'Is're pié et protohistorique: Gallia Préhist., v. 12, 110. 2, p. $315-316$.

Bonuet, A. Bonnet, E, and Malaval, M., 1971, Résultats próliminaires obtenus au cours de nouvelles fouilles réalisces dans la grotte de La Sartanette a Remoulins, Gard: Soc. Etudes Sci. Nat. Nîmes Bull, v. 51.p $381-403$.

Bourdelle, Y., Delporte, H., and Vernon, J., 1971, Le risement magdalénien et la "Vémus" d'Enval, communc de Vic-le-Come: l'Anthopologie, v. 75, p. $119-128$.

Bourdier, F. atnd de Lumley, II., 1956, Magdalénien et Romanello-Azilien en Dauphiné: Mus. Anthtopol. Préhist. de Monaco Bull., v. 3, p. 128-176.

Brocker, W. S. and Kulp, J. I.., 1957, Lamont natural radiocarbon measunements IV: Scicuce, v. 126, p. 1324-1334.

Caillaud, R. and Lagnel, E., 1971, Le 'Iumulus de La IIoguette: Gallia Préhist., in piess.

Camps, G., Delibrias, G., and Thommeret. I., 1968, Chronologie absolue et succession des civilisations próhistoriques dans le Nord de l'Afrique: I,ybica, v. 16, p. 9-28.

Cordier, (;, 1963, Quelques mots sur les pirogues monoxyles de Irance: Soc. frangaise Préhist. Bull., v, 60, p. 307.

David, L. et al., 1972, Datation par le radiocarbone de la terrasse quaternaire de Saint-Rambert-d'Albon, 1)rónc: Acát. sci. [Paris] Comptes rendus, ser. 1), v. 274, p. $2007-2008$.

Delibrias, G., Guillier, M. T., and Labeyric, J., 1966, Gif natmal radiocarbon measurements II: Radiocarbon, v. 8, p. 74-95. 443. 1970, Gif natural radiocarbon measurements v: Radiocarbon, v. 12, p. 121-

1972, Gif natural radiocarbon measurements VII: Radiocarbon, v. 14, p. $280-320$

Desbrosse, R., 1969, Les fouilles préhistoriques en Bugey en 1968-1969: Annales du Bugey, v. 50 , p. 43-59

Escalon de Fonton, M., 1970, Ies civilisations Néolithiques du Midi de la Fance: Cong. Préhist. Proc, Narbonme, lieb. 1970, in press.

Evin, J. and Desbrosse, R., 1971, Datations an $C^{44}$ de gisements Magdalćniens du Jura ct des Préalpes du Nord: 8 h internatl. cong. Union Préhist. and Protohist. sci. Proc., Belgrate, Sept. 1971, in press.

Evin, I., Longin, R., and Pachiaudi, Ch., 1969, Lyon natural radiocarbon measurements I: Ridiocarbon, v. 11, p. 112-117.

Evin, J., Iongin, R., Marien, G., and Pachiaudi Ch., 1971, Lyon natual radiocabon measurements II: Ratiocatbon, v. 13, p. 52-73.

Felber, Heinz, 1970, Vicmua Radium Institute radiocarbon dates I: Radiocarbon, v. 12, p. $298-318$

Gauthier, II., 1955, Information des antiquites historiques de la Franche-Comté: Gallia Prohist., v. 13, p. 110.

Jayet, A., I932, Le paléolithique de la region de Genive: Le Globe, v. 22.

Labeyrie, J. et al., 1967; Ftude des tempéaulues des climats anciens par la mesure $\mathrm{O}^{1 \mathrm{~s}}$ $\mathrm{C}^{13}$, C.14, dans les concrétions des cavernes: I.A.E.A., conf. on radioactive dating and methods of low level comting Proc., Monaco, p. 153-159.

Laurent, R., 1968, Apparition de la metallurgie du fer dans les stations littorales du Bromze final: Soc. limmécnne Lyon Bull., 37 eme annéc, no. 4, p. 150-158.

I.celaire, L., 1970, Aspect of late quaternary sedimentation on the Algerian precontinent and the adjacent Algetian-Balearic bassin: 8th internatl. sedimentology cong. Proc., Heidelberg, in press. 
Longin, R., 1971, New method of collagen extraction for radiocarbon dating: Nature, v. 230 , p. $241-242$.

Mayed, L. and Pissot, J., 1915, Abri sous roche préhistorique de La Colombiere près de Poncin, Ain: Aninales Univ. Yyon, ser. 1, v. 39, $205 \mathrm{p}$.

Nomer, C., Nourer, R., and Thomnerct, Y., 1970, Premieres datations absolues de lhahilat prehistorifue de la Grotle de Liang-Spean (Cambodge); Acad. sci. Paris| Compres rendus, v. 270, p. 471-47\%.

Movius, H. I. and Judwon, S., 1956 , The rockshelter of La Colombiore: Archeological and geological investigations of an Upper Perigordian site near Poncin, Ain: Cambridge, Peabody Mus. Press.

Pétrecpuin, P.. 1970, La Grotte de Ia Balme de Gonvillard: Annales lit., Lniv. Besalicon, $1970,186 \mathrm{p}$.

Pradel, L. and Pradel, J. II., 1960, Magdalenien et Azilien de 1'Alıi des Douattes, commune de Mussieges, Hante-Savois: Soc. francatise Prchist. Bull, v. 57, p. 75-79.

Roudil, J. L., 1969, Lhalbitat campaniforme de Saint-Come et Maruéjols, Giard: Soc. franciase Prohist. Bull., v. 66, no. 3, p. $88-91$

Rubin, Mever and Suess, H. E., 1955, U.S. Geological Survey radiocarbon dates II: Scicnce, v. 121, p. 481-488.

Tamers, M. A., I965. Koutine ("1" dating using liquid scintillation technique: 61h intenatl. conf on $\mathrm{C}^{14}$ and $\Gamma^{3}$ dating Proc., Pullman, Washington, 1965.

Thommeret, ]. and Thommeret, Y,, 1969, Monaco radiocarbon measurements III: Radicacarbon, v. 11, p. $118-129$.

Toumicr, I. and Costa de Baturegard, T. J922, Deux stations prohistoriques du Jura dans lit vallée de l'Ain et dans la vallée du Suran: l'Anthopologic, v. 32, p. $38,-408$

Vanbrugehe, R. and Bili, J., 1968, la grotte du Seuil des Chères à Ia Balme, Savoie, fouilles de 1967: Soc limnéenne Lyon Bull., 37ì annće, no. 4, p. 150-158.

rilain, R., 1966, Le giscment de Sous-Bbitme it Culoz (Ain) et ses industries microlithicues: Lab. Géol., Fic. Sci. I.yon doc., v. 13,220 p.

V'imont, E., 1884, Le camp de Bierre: Soc. hist, archéol. Orne Bull., v. 3, p. 198-210. 